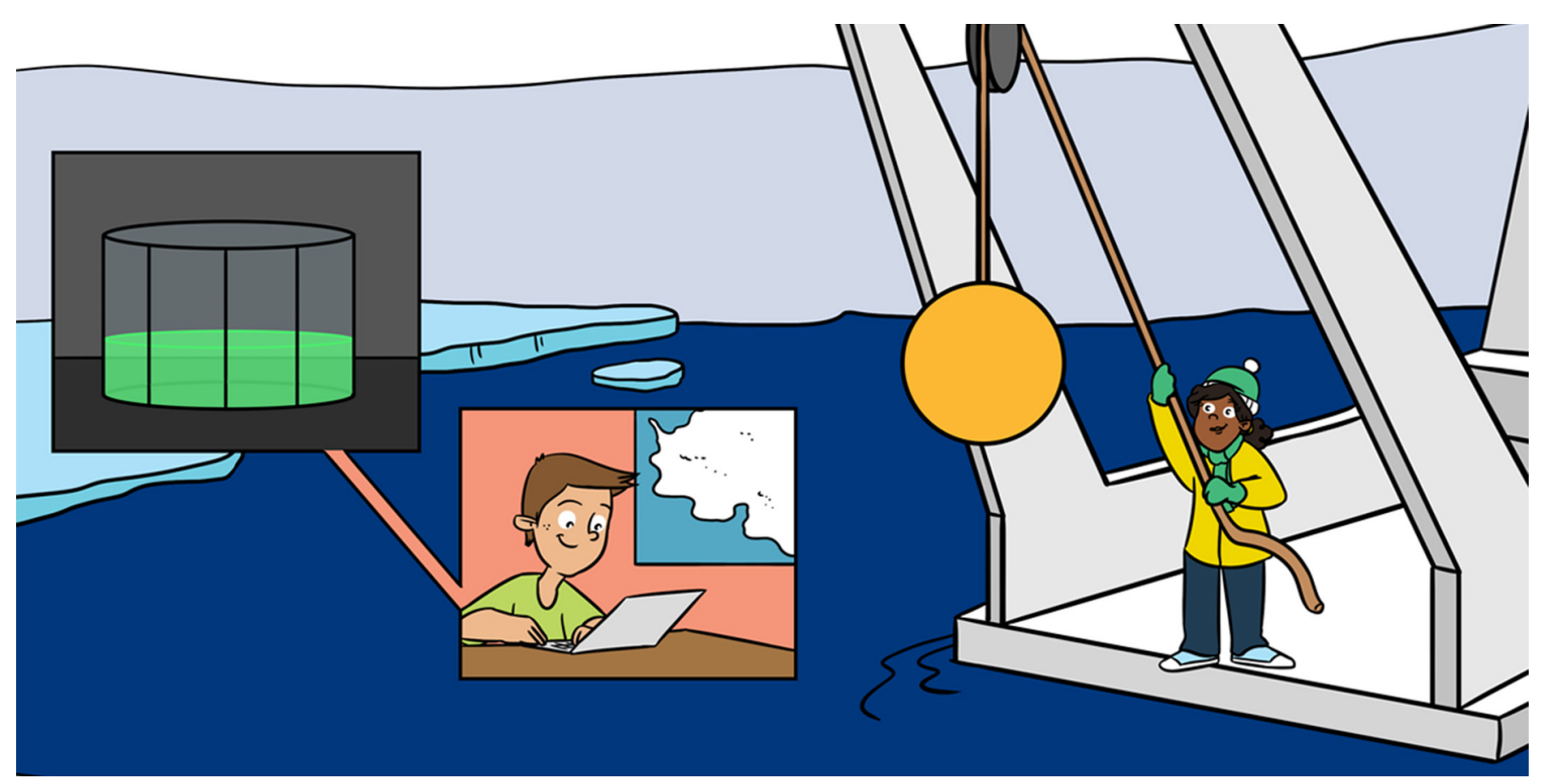

\title{
ARE WARM OCEAN CURRENTS MELTING THE ICE IN ANTARCTICA?
}

\author{
Mirjam S. Glessmer ${ }^{1 *}$, Nadine Steiger ${ }^{2}$, Elin Darelius ${ }^{2}$ and Anna Wåhlin ${ }^{3}$ \\ ${ }^{1}$ Fascinocean, Kiel, Germany \\ ${ }^{2}$ Faculty of Mathematics and Natural Sciences, Geophysical Institute, University of Bergen, Bergen, Norway \\ ${ }^{3}$ Department of Marine Sciences, University of Gothenburg, Gothenburg, Sweden
}

\section{YOUNG REVIEWERS:}

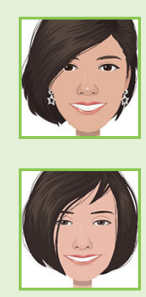

ISABEL

AGE: 9

MARGARIDA

AGE: 12

\section{ICE SHEET}

Large ice masses that cover Greenland and Antarctica. They form as it snows and rains and more and more ice accumulates, and can be up to $5 \mathrm{~km}$ thick.
We went to Antarctica on a research ship to set out instruments, which stayed in the water and took measurements for 2 years. While the instruments were out, we went to a research facility and had a swimming pool full of water turn around on a big merry-go-round for 2 months. We did all this to understand whether warm currents are melting ice in Antarctica [1]. What was the answer? Let us start from the beginning...

\section{VERY COLD AND VERY FAR AWAY: A FROZEN CONTINENT AND ITS IMPORTANCE}

Antarctica-the huge landmass at the South Pole-is the only continent that nobody lives on permanently (Figures $1 \mathrm{~A}-\mathrm{D}$ ). It is very cold-the average temperature is $-10^{\circ} \mathrm{C}\left(14^{\circ} \mathrm{F}\right)$ near the coast and $-60^{\circ} \mathrm{C}\left(-76^{\circ} \mathrm{F}\right)$ in the interior. Antarctica is almost completely covered in a sheet of snow and ice. This ice sheet is up to $5 \mathrm{~km}$ (3 miles) thick 
Figure 1

(A) A map of Antarctica and the region we are specifically interested in (red box). (B) The green dots mark the locations of our moorings. (C) This is what an ice shelf would look like if it were cut open and looked at from the side. Part of it rests on land and the sea floor. It is flowing toward the open ocean, and gradually thinning due to melting. Parts of the ice shelf break off and float away. A current of relatively warm water flows toward the ice shelf at the sea floor. (D) The research ship RV Shackleton on one of its journeys to Antarctica, laying moored near an ice shelf.

\section{ICE SHELVES}

Large ice sheets that flow off land and float on the ocean, but are still connected to the ice that is still resting on land. They can be several hundreds of meters thick.

\section{SEA ICE}

Ice that forms when sea water freezes. It floats on the ocean (see https://kids.frontiersin .org/article/10.3389/ frym.2019.00079).

\section{SEA-LEVEL RISE}

Long-term average rise of the ocean's water level. The melting of Antarctic and Greenland ice caps is contributing to sea-level rise.
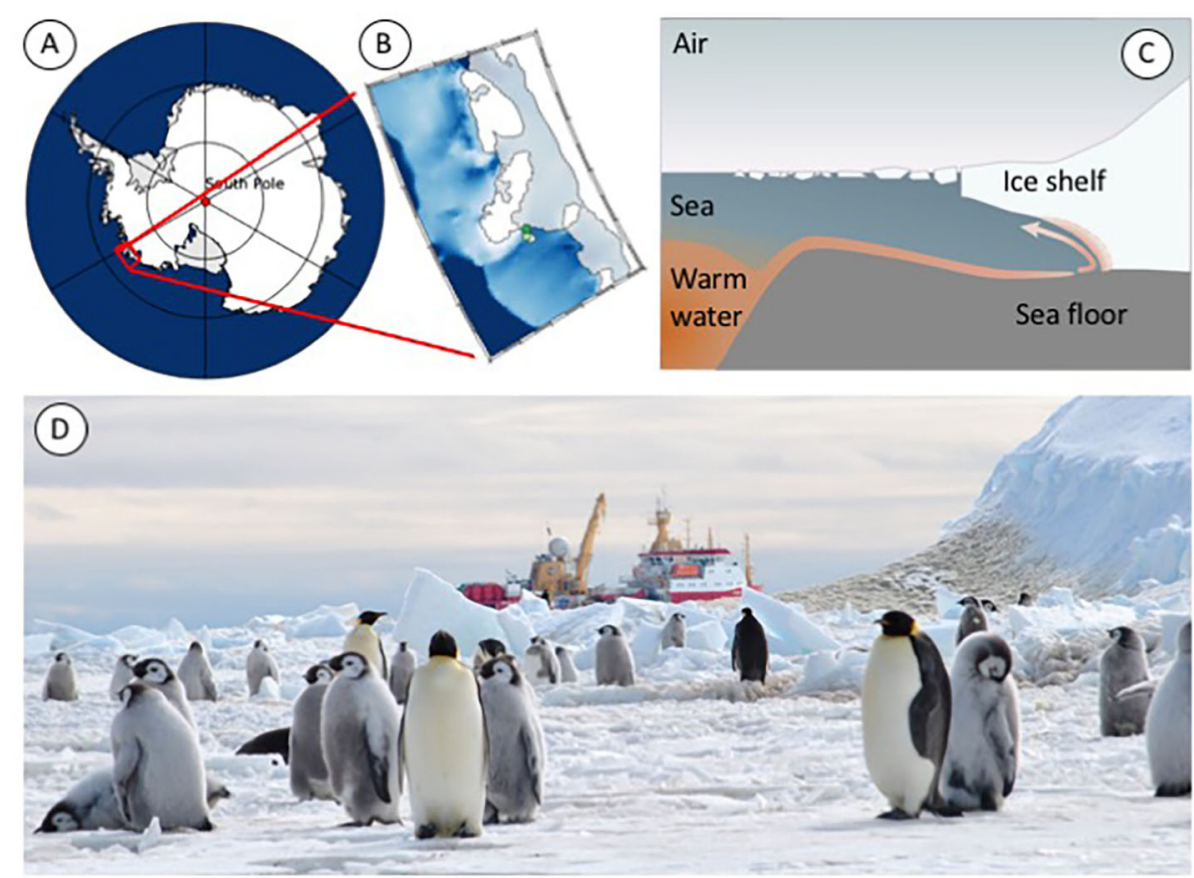

Figure 1

and grows thicker as snow falls on it. The parts of an ice sheet that float on the ocean but are still attached to the ice sheet are called ice shelves. They can extend for many kilometers away from the land. There, big ice bergs break off and leave a wall of ice that reaches 250-500 m (820-1,640 ft) down into the ocean.

It is important to distinguish ice shelves and ice bergs from sea ice, even though all three float on the ocean [2]. Sea ice forms when water in the ocean freezes, similar to ice that forms on lakes. When sea ice melts, it does not add extra water to the ocean, thus sea level does not change. Ice that originates on land, however, causes sea-level rise when it melts. The glaciers on Antarctica start out as an ice sheet resting on land, but their offshore parts float on the ocean. Those parts act as a stopper that keeps the rest of the ice on land. If the floating ice melts, more ice will slide from land into the ocean and cause sea-level rise.

The worst-case estimates predict that the sea level could rise 5 $\mathrm{cm} /$ year (2 in/year). This is really fast! Imagine a spot near the ocean where you get slightly wet toes right now. Forty years from now, the water level could already be above your head! It is important to be able to predict how fast sea level will rise so that we can prepare for it. Therefore, we need to understand how much ice is really melting and what causes melting. 


\section{CLIMATE CHANGE}

The long-term change in climate patterns like temperatures, precipitation, ocean currents, and sea levels Climate change occurs naturally and leads to warm and cold periods, but most recently it is caused by humans.

\section{OCEAN CURRENT}

The average motion of water in the ocean. Ocean currents can be driven by different processes, like the wind or density differences in the water (see my article https://kids.frontie rsin.org/article/10.3389/ frym.2019.00085).

\section{MOORING}

Oceanographic instruments that are anchored to the sea floor and stay in the ocean for a certain time period to collect data. Moorings can measure ocean currents and the temperature and salinity of sea water

\section{THE OCEAN IS MELTING ANTARCTICA'S ICE}

Ice has been melting faster over the last decades because of climate change, due to warmer air temperatures and because more ice is breaking off and floating away, but also because of the warmer water around Antarctica [3]. The world's strongest ocean current circles all around Antarctica. In some places it brings relatively warm water $\left(1-2^{\circ} \mathrm{C} ; 34-36^{\circ} \mathrm{F}\right)$ toward the ice shelves [4], warm enough to melt ice if water and ice contact each other. But do they?

Since the sea floor around Antarctica is full of narrow, deep valleys, those canyons could funnel the warm water toward the ice, similar to water slides that funnel you down into the swimming pool. If the currents manage to flow underneath the ice shelves, this could increase melting from below. The thinner the floating ice shelves become, the faster ice will slide off Antarctica.

But it is difficult for warm currents to get underneath the floating ice shelves. At their thinnest parts, they still reach $250-500 \mathrm{~m}$ deep into the water. Imagine the ocean as a room with the ocean surface as its ceiling: the ceiling would suddenly drop by $250-500 \mathrm{~m}$ where the ice shelves start. This change in height makes it more difficult for currents to flow underneath. In our imaginary room, people wanting to go underneath the dropped ceiling might have to duck or even crawl, which some might be better at than others. Similarly, there are different kinds of currents - those that stay close to the ground and dive below an obstacle, and those that cannot. But which sort of currents do we have around Antarctica, and does the warm water actually get close enough to the ice to melt it? There are several ways to find out.

\section{FIGURING OUT HOW FAST THE ICE IS MELTING, AND WHY}

It seems like we could easily take a research ship, sail to Antarctica, and observe the currents directly. But there are several reasons why this is not easy. The weather there is bad and the ocean is covered in sea ice during winter, threatening ships, and crews. Therefore, data taken from research ships only exists in selected locations for short periods of time, and only in summer.

An alternative are instruments that stay in the ocean for long periods of time (Figure 2). Moorings are anchored to a fixed location on the ocean floor, thus giving measurements in that location specifically. Floats are drifting with the currents and therefore provide data only where the currents take them. Instruments can also be mounted on seals, giving data wherever the seals choose to swim. Gliders are like small submarines and move slowly, remotely controlled through the water, but need a research ship nearby. And, even for instruments, it is dangerous to be too close to the ice edge-there is a lot of both 
Figure 2

(A) A mooring in the ocean, showing the anchor that keeps it in place, the buoys that keep it upright, and the various instruments to measure the water's temperature, how much salt there is in the water, and the direction and speed of the currents. (B) A mooring being deployed over the stern of a research ship. The large orange ball hanging on the crane is a buoy that carries instruments that will measure currents and that keeps the mooring upright in the water. Behind the research ship, you can see other parts of the mooring already floating in the water. (C) A map of our mooring sites (same as Figure 1B, only rotated). (D) The results from our three moorings: arrows show the direction that the currents are flowing, colors show the temperatures of those currents.

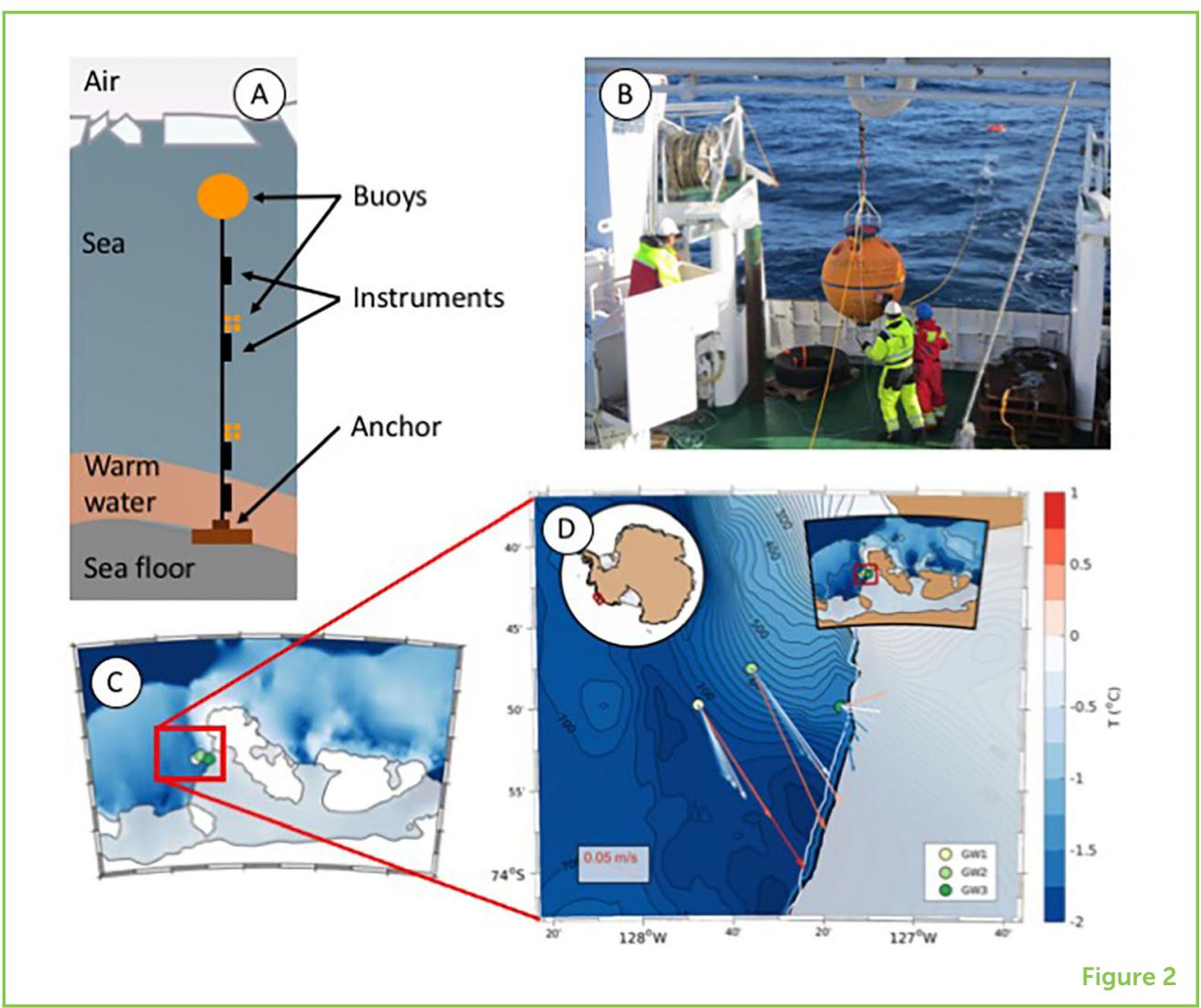

skill and luck involved in deploying and recovering instruments! It stays exciting until the very end: will we find the instruments again, get them back on board, and will they actually have recorded for the full period of time they were in the ocean? The data can only be read from the instruments when they are safely back on board the ship.

A second approach to understanding the warm currents and ice shelves is to simulate the system by building it in miniature (imagine a model railway). Then, we can change the shapes of the ice shelves or the canyons in our model, for example, to understand the impact of each change on the current's behavior in the real world.

\section{MEASURING DIRECTLY IN THE OCEAN}

We set out moorings with instruments that can tell us about water temperature and the direction and strength of ocean currents at three sites over a period of 2 years: one right at the front of the ice shelf and two along a canyon that funnels water towards the ice shelf. Data from two moorings showed water flowing toward the ice shelf. The third mooring, closest to the ice shelf, showed the current turning just before reaching the ice shelf. That means the current's warm water does not continue straight underneath the ice shelf. Instead, it turns and flows along the front of the ice shelf before flowing back into the 
Figure 3

(A) An outside view of the $13 \mathrm{~m}$ diameter rotating swimming pool. Note the control room that rotates with the pool, as well as the "ice shelf" and "canyon" in the water. (B) A top view of the model canyon (blue) underneath the ice shelf (yellow). The current (red) is flowing underneath the ice shelf, then turns and flows out again.

\section{COMPUTER MODEL}

A way to represent physical processes on a computer that allows scientists to understand an environment, or predict the effect of future changes.

Weather forecasts are an example. For a good explanation

see https://kids.frontiersin org/article/10.3389/frym 2019.00161.

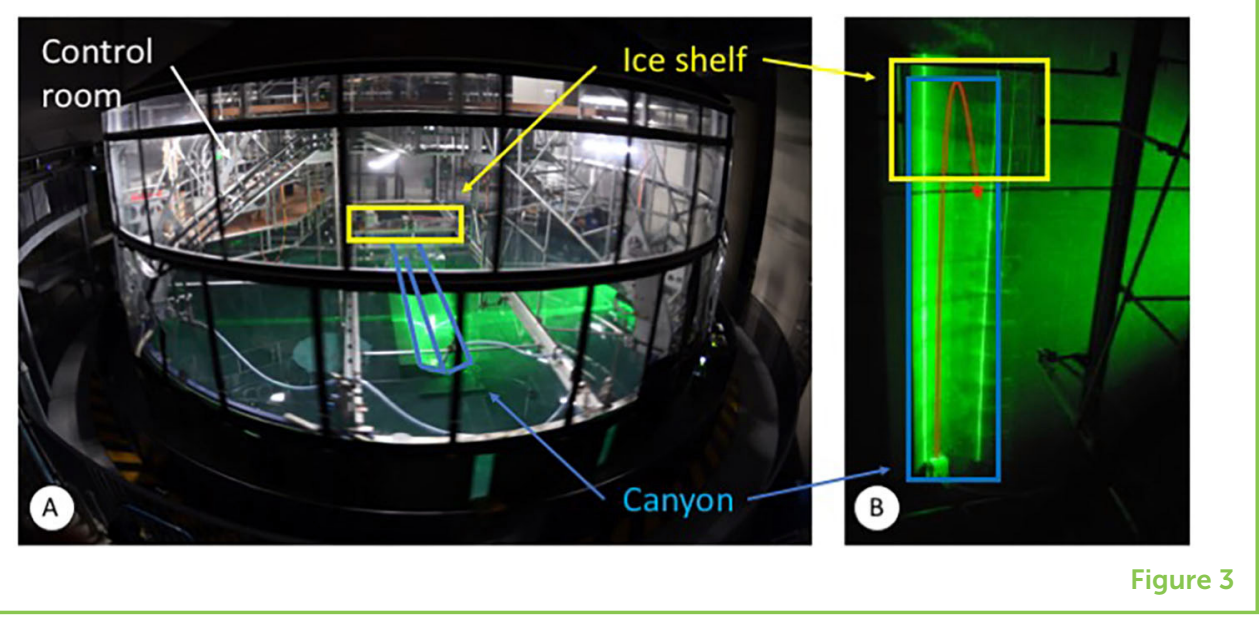

open ocean. Therefore, the ice is not melting as much as it would if the current went underneath the ice shelf.

\section{RECREATING OCEAN CURRENTS IN A MINIATURE WORLD}

In the lab in Grenoble, France, we found the explanation for why the current turns around (Figure 3). We used a $13 \mathrm{~m}$ diameter pool that rotates, simulating Earth's rotation. We built a plastic canyon to represent our area of interest in Antarctica. We then pumped water into the canyon to create a current. The end of the canyon was covered by a plastic "ice shelf" that we could rise, lower, and tilt to create different conditions. We made the currents visible by mixing little plastic particles into the water and lighting them with lasers. Following where particles moved between photographs of the laser-lit particles, we could reconstruct the currents.

For an ice shelf that starts with a steep step, the current nibbles at the ice edge, but it is forced to turn around without flowing underneath the ice. With only very little water movement underneath the ice, there is little melting there. However, if the shape of the ice sheet is changed so that it starts at the sea surface and then gradually reaches deeper into the water, it is easier for currents to move under the ice. An ice shelf of that shape will melt faster. Also, if the structure of the current changes such that only the lower part is moving, it might behave differently, and more water might be able to get under the ice shelf.

\section{PREDICTING THE FUTURE}

Now that we know how the shape of the ice shelves as well as the type of currents approaching them influence how fast ice melts, we can use that to help predict future sea levels. Computer models, similar to those used for weather forecasts, can accurately calculate where 
the ocean currents go and how much ice they melt. This information then becomes one piece in the puzzle of climate predictions that can help make policy decisions to both prevent and adapt to changing sea levels.

\section{ACKNOWLEDGEMENTS}

The authors would like to thank K. Daae for assistance with illustrations. Our experiments were supported by the European Union's H2020 programme through the grant to Hydralab-plus, contract number 654110. We gratefully acknowledge grant support for the authors as follows: ED and NS from the Norwegian Research Council through grants 267660 (TOBACO) and 231549 (WARM); AW from the Swedish Research Council and the Swedish Foundation for Strategic Research through the Swedish Maritime Robotics Center (SMaRC); We thank I. Fer for lending instrumentation for GW1 and GW2.

\section{ORIGINAL SOURCE ARTICLE}

Wåhlin, A. K., Steiger, N., Darelius, E., Assmann, K. M., Glessmer, M. S., Ha, H. K., et al. 2020. Ice front blocking of ocean heat transport to an Antarctic ice shelf. Nature 578:568-71. doi: $10.1038 / s 41586-020-2014-5$

\section{REFERENCES}

1. Wåhlin, A. K., Steiger, N., Darelius, E., Assmann, K. M., Glessmer, M. S., Ha, H. K., et al. 2020. Ice front blocking of ocean heat transport to an Antarctic ice shelf. Nature 578:568-71. doi: 10.1038/s41586-020-2014-5

2. Glessmer, M. S. 2019. How does ice form in the sea? Front. Young Minds 7:79. doi: 10.3389/frym.2019.00079

3. Shepherd, A., Fricker, H. A., and Farrell, S. L. 2018. Trends and connections across the Antarctic cryosphere. Nature 558:223-32. doi: 10.1038/s41586-018-0171-6

4. Assmann, K. M., Darelius, E., Wåhlin, A. K., Kim, T. W., and Lee, S. H. 2019. Warm circumpolar deep water at the western getz ice shelf front, Antarctica. Geophys. Res. Lett. 46:870-8. doi: 10.1029/2018GL081354

SUBMITTED: 28 February 2020; ACCEPTED: 07 August 2020; PUBLISHED ONLINE: 09 October 2020.

EDITED BY: Carolyn Scheurle, Institut de la Mer de Villefranche (IMEV), France

CITATION: Glessmer MS, Steiger N, Darelius E and Wåhlin A (2020) Are Warm Ocean Currents Melting the Ice in Antarctica? Front. Young Minds 8:124. doi: 10. 3389/frym.2020.00124 

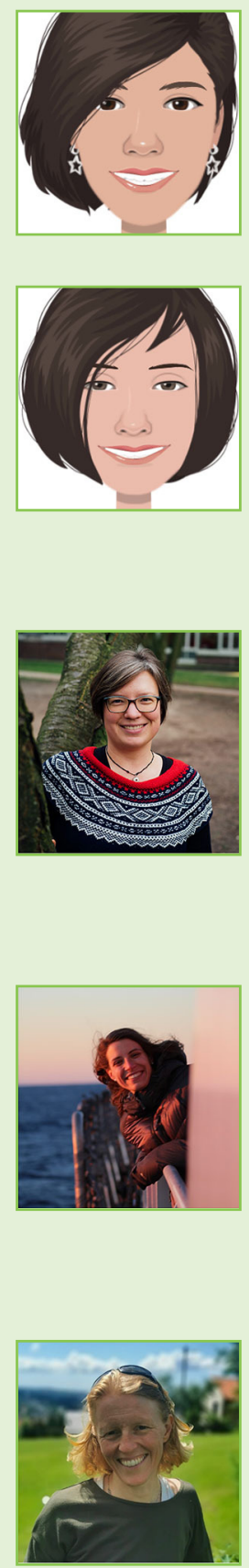

CONFLICT OF INTEREST: The authors declare that the research was conducted in the absence of any commercial or financial relationships that could be construed as a potential conflict of interest.

COPYRIGHT @ 2020 Glessmer, Steiger, Darelius and Wåhlin. This is an open-access article distributed under the terms of the Creative Commons Attribution License (CC BY). The use, distribution or reproduction in other forums is permitted, provided the original author(s) and the copyright owner(s) are credited and that the original publication in this journal is cited, in accordance with accepted academic practice. No use, distribution or reproduction is permitted which does not comply with these terms.

\section{YOUNG REVIEWERS}

\section{ISABEL, AGE: 9}

$\mathrm{Hi}$, I am Isabel and I am from Portugal. I am 9 and I like reading, writing, and music. I have three cats and I like to learn about history. I have no idea of what I want to be when I grow up. I really like vegetables (and fruit).

\section{MARGARIDA, AGE: 12}

My name is Margarida, I am 12 years old and I like reading, climbing, and writing. I love science, especially anything about black holes, and I have absolutely no idea what I want to do when I grow up. I also really like biology.

\section{AUTHORS}

\section{MIRJAM S. GLESSMER}

Dr. Mirjam S. Glessmer is a physical oceanographer. She is fascinated by water in all its forms: she loves to go "wave watching" on puddles, streams, or the sea, or to do experiments on ocean physics using only household items ("kitchen oceanography"). Mirjam is passionate about sharing her fascination with all things related to ocean physics and you are welcome to contact her if you have questions, at www. mirjamglessmer.com/contact or *mglessmeragmail.com

\section{NADINE STEIGER}

Nadine Steiger is a Ph.D. student in physical oceanography and is learning a lot about the ocean. She loves the magic of the polar regions with all the beautiful ice-how does it connect with the ocean and the rest of the climate system? So far, she is already had the chance to go on a research cruise to Antarctica and she worked for 2 months on the rotating platform in France, mesmerized by the green light that visualizes the currents in the water.

\section{ELIN DARELIUS}

Dr. Elin Darelius is a polar researcher and a physical oceanographer working at the University of Bergen. She loves ice and cold water (but not for swimming) and she has been on four research cruises to Antarctica. She helped deploy the moorings that were used in this study, and she went swimming in the rotating pool in France 
(where the ice shelf was plastic and the water was nice and warm). You are welcome to visit her blog (https://skolelab.uib.no/blogg/darelius/) to read more about what she does.

\section{ANNA WÅHLIN}

Professor Anna Wåhlin is a physical oceanographer. She is fascinated by water and ice, and how water and ice interact in the polar seas on Earth. To understand the ocean, she goes on research cruises to collect data, but she also works with laboratory experiments and computer models. She enjoys teaching students about the physics of the oceans at her university, which is situated in Gothenburg, a small city on the West coast of Sweden. 